\title{
PENGUATAN PERAN EKONOMI ISLAM MELALUI OPTIMALISASI PEMBIAYAAN PADA SEKTOR RIIL UMKM
}

\author{
Trimulato; Ismawati; Amiruddin K; Nuraeni \\ Universitas Islam Negeri Alauddin Makassar \\ e-mail: trimsiuii@yahoo.co.id; ismaabbas@uin.ac.id; amiruddin@uin.ac.id; \\ nuraenigani@gmail.com
}

\begin{abstract}
Islamic economic in Indonesia continues to experience very rapid growth, seen by the increasing number of institutions operating in sharia principles, in addition to the growing and developing businesses with sharia principles. The development of the Islamic economy is inseparable from the role of various parties who continue to try to socialize the Islamic economy to society. The government seems to be very serious in supporting the development of the Islamic economy in Indonesia. It looks at the Islamic financial market share that has not enough 10 percent, so it requires more efforts for its development. It needs to determine the direction and focus on particular segments to develop so they can compete globally. The right segment chosen for the Islamic economy is the development of SMEs, given that it grows and develops in Indonesia. This study aims to find out the development of SMEs and map the strengthening of the Islamic economy through financing for SMEs. The type of research is library research and is qualitative. Data collection techniques used are through retrieval data has been there before. The data analysis technique used is descriptive qualitative, related to the development SMEs and Islamic economic institutions. Results showed that development in 2018 SMEs experienced growth, mediumsized businesses grew by 3.54 percent, and small businesses grew by 3.44 percent, while the largest portion of SMEs was microbusinesses, which amounted to 98.7 percent. Distribution financing sharia banking is still dominated by consumer consumption rather than productive. Islamic economic institutions are experiencing growth, so they can be directed to develop SMEs. Strengthening it can be done by selecting certain segments that are the focus is SMEs. The concept of profit-sharing inherent in Islamic economic transactions is very relevant to the development of SMEs.
\end{abstract}

Keywords: Islamic economic; financing; SMEs

\section{Pendahuluan}

Ekonomi Islam muncul dari refleksi atas kekäfahan keislaman seorang muslim. Ekonomi Islam merupakan bentuk evolusi atas teori ekonomi neo klasik. Ekonomi Islam muncul di saat perekonomian modern lambat dalam menghadirkan solusi atas problematika ekonomi kontemporer, kalau tidak boleh dikatakan tidak mampu untuk menghadirkan alternatif solusi. ${ }^{1}$ Ilmu ekonomi Islam adalah sebuah sistem ekonomi yang menjelaskan segala fenomena tentang perilaku pilihan dan pengambilan keputusan dalam setiap unit ekonomi dengan memasukkan tata aturan syariah sebagai variabel indevenden (ikut mempengaruhi segala pengambilan keputusan ekonomi).

\footnotetext{
${ }^{1}$ Abdul Sami’ al-Mishri, Pilar-Pilar Ekonomi Islam (Yogyakarta: Pustaka Pelajar, 2006), ix.
} 
Dari sudut pandang ilmu fikih, kegiatan ekonomi bukanlah termasuk ibadah mahdah, melainkan mu'amalah. Oleh karena itu, berlaku kaidah fikih yang menyatakan bahwa al-aṣl fi al-mu'ämalah al-ibaḥah illā idhā mà dalla al-dalil 'alā khiläfih, yakni suatu perkara muamalah pada dasarnya diperkenankan halal untuk dijalankan kecuali jika ada bukti larangan dari sumber agama (al-Quran dan Sunnah). Oleh karena itu tidak dibenarkan melarang sesuatu yang dibolehkan Allah, sebagaimana tidak boleh pula membolehkan sesuatu yang jelas hal itu dilarang. ${ }^{2}$

Ekonomi Islam memiliki pandangan bahwa seluruh harta kekayaan yang ada di alam ini harus dialokasikan secara adil menurut aturan syariah Islam. Dalam ekonomi Islam, harta kekayaan tidak langsung mengalokasikan seluruh harta kekayaan itu ke dalam mekanisme pasar, sebagaimana yang ada dalam tubuh ekonomi kapitalisme. Di dalam ekonomi pasar syariah, seluruh harta kekayaan yang ada harus menjalani tiga tahap penyaringan, yaitu prapasar, mekanisme pasar, dan pascapasar. Sebelum harta kekayaan masuk ke dalam mekanisme pasar, maka seluruh harta kekayaan tersebut terlebih dahulu harus disaring dalam tahapan penyaringan prapasar. Pandangan ekonomi Islam harta itu harus dipilah atau dibagi terlebih dahulu menurut jenis kepemilikannya. Pembagian kepemilikan harta dalam pandangan ekonomi Islam dibagi menjadi tiga, yaitu kepemilikan individu, kepemilikan umum, dan kepemilikan negara. Manfaat tentu akan dapat terlihat secara langsung, yaitu limpahan sumber daya alam akan langsung dikelolah negara, selanjutnya akan dipergunakan untuk sebesar-besarnya kemakmuran rakyat. $^{3}$

Ekonomi Islam bukan hanya bertujuan untuk meningkatkan taraf kehidupan dalam sebuah negara semata, tanpa memperhatikan terjamin tidaknya tiap orang untuk menikmati kehidupan tersebut. Ekonomi Islam juga bukan hanya bertujuan untuk mengupayakan kemakmuran individu dengan membiarkan mereka sebebas-bebasnya untuk memperolah kemakmuran tersebut dengan cara apapun, tanpa memperhatikan terjamin tidaknya hak hidup setiap orang. Ekonomi Islam adalah semata-mata merupakan pemecahan masalah utama yang dihadapi tiap orang sebagai manusia yang hidup sesuai dengan interaksi-interaksi tertentu, serta memungkinkan orang yang bersangkutan untuk meningkatkan taraf hidupnya, dan mengupayakan kemakmuran dirinya di dalam gaya hidup islami. Hukum-hukum Islam telah menjamin tercapainya pemenuhan seluruh kebutuhan primer tiap warga negara Islam secara menyeluruh, seperti sandang, papan dan pangan. Caranya adalah dengan mewajibkan bekerja tiap laki-laki yang mampu bekerja sehingga dia bisa memenuhi kebutuhan primernya sendiri beserta orang-orang yang nafkahnya menjadi tanggungannya. Kalau orang tersebut tidak mampu bekerja, maka Islam mewajibkan kapada anak-anaknya serta ahli warisnya untuk memenuhi kebutuhan primernya. Atau, jika yang wajib menanggung nafkahnya tidak ada, maka bayt al-mal yang wajib memenuhinya. ${ }^{4}$

Ekonomi Islam dibangun atas dasar agama Islam, karenanya ia merupakan bagian tidak terpisahkan integral dari agama Islam. Sebagai derivasi dari agama Islam, ekonomi Islam akan mengikuti agama Islam dalam berbagai aspeknya. Islam adalah sistem kehidupan (way

\footnotetext{
${ }^{2}$ Adiwarman A. Karim, Ekonomi Mikro Islam, edisi 3 (Jakarta: PT Raja Grafindo Persada, 2006), 5.

${ }^{3}$ Dwi Condro Triono, Ekonomi Pasar Syariah Ekonomi Islam Madzhab Hamfara, jilid 2 (Yogyakarta: Irtikaz, 2017), 175.

${ }^{4}$ Taqiyuddin al-Nabhani, Membangun Sistem Ekonomi Alternatif Perpektif Islam (Surabaya: Risalah Gusti, 2009), 55.
} 
of live) yang akan membawa manusia ke kondisi yang lebih baik sesuai dengan tujuan hidupnya. Ekonomi Islam dibangun untuk tujuan suci, dituntun oleh ajaran Islam dan dicapai dengan cara-cara yang ditentukan pula oleh ajaran Islam. Oleh karena itu, semua hal tersebut saling terkait dan terstruktur secara hirarkis, dalam arti bahwa spirit ekonomi Islam tercermin dari tujuannya dan ditopang oleh pilarnya. Tujuan untuk mencapai falah hanya bisa diwujudkan dengan pilar ekonomi Islam, yaitu nilai-nilai dasar (islamic values) dan pilar operasional yang tercermin dalam prinsip-prinsip ekonomi Islam. Dari sinilah akan tampak suatu bangunan ekonomi Islam dalam suatu paradigma, baik paradigma dalam berfikir dan berperilaku maupun bentuk perekonomiannya. ${ }^{5}$

Ekonomi Islam mengalami kebangkitan setelah tenggelam dalam sejarah beberapa abad yang silam. Ekonomi Islam kini kembali sebagai solusi dari sistem perekonomiaan yang ada saat ini yang sudah dianggap gagal dalam mengatur kehidupan manusia. Ekonomi Islam tetap akan berkosentrasi pada aspek alokasi dan distribusi sumber-sumber daya dengan tujuan utamanya merealisasikan maqāsid. Suatu perekonomian dapat dikatakan adil jika barang dan jasa yang diproduksi dapat didistribusikan dalam suatu cara di mana kebutuhan individu (tanpa memandang apapun) dapat dipenuhi secara memadai dan juga terdapat distribusi kekayaan dan pendapatan yang adil tanpa berdampak buruk pada motivasi kerja, menabung, investasi, dan melakukan usaha. ${ }^{6}$

Bentuk fokus pengembangan ekonomi Islam di negara ini yaitu berupa pengembangan ekonomi Islam pada segmen usaha mikro, kecil dan menengah (UMKM). Mengingat, banyaknya UMKM di negara ini yang menjadi penopang perekonomian dan banyak menyerap lapangan kerja. Kondisi UMKM di Indonesia terus tumbuh dan berkembang, tetapi selalu terkendala masalah modal. Sehingga ekonomi Islam dapat menjadi jalan dalam pengembangn UMKM. Lembaga-lembaga ekonomi Islam dapat diarahkan untuk mendukung modal bagi UMKM. Jika di Malaysia lembaga keuangan Islam banyak dimanfaatkan untuk membiayai usaha-usaha dan proyek yang besar, maka ekonomi Islam sebaiknya diarahkan untuk berkontribusi dalam mengembangkan UMKM, pelaku UMKM yang begitu banyak, dan tersebar luas sampai kepedesaan, dan melibatkan segmen menengah ke bawah akan mendukung literasi keuangan yang tepat.

Saat ini perkembangan UMKM sangat baik dengan porsi 99\% dari total usaha. Dari data Badan Pusat Statistik tentang perkembangan UMKM dari Kementerian Koperasi dan Kecil dan Menengah menunjukkan data pada tahun 2017 jumlah UMKM sebesar 62.922.617, dan pada tahun 2018 64.194.057, atau mengalami pertumbuhan sebesar 2,02 persen. Keberadaan UMKM belum menjadi prioritas bagi bank Islam dalam menyalurkan pembiayaan tetapi masih didominasi untuk keperluan konsumtif.

Tabel 1.1. Pembiayaan UMKM di Bank Syariah

\begin{tabular}{|c|l|c|c|}
\hline No & Produk Pembiayaan & Oktober 2019 & Porsi Pembiayaan \\
\hline 1 & Konsumsi (Bukan UMKM) & 89.638 & $41 \%$ \\
\hline 2 & Investasi & & \\
& a. UMKM & a. 18.345 & a. $8,4 \%$ \\
& b. Bukan UMKM & b. 32.373 & b. $14,8 \%$ \\
\hline
\end{tabular}

\footnotetext{
${ }^{5}$ P3EI UII, Ekonomi Islam (Jakarta: PT. Raja Grafindo Persada, 2008), 53.

${ }^{6}$ M. Umar Chapra, Masa Depan Ilmu Ekonomi Sebuah Tinjauan Islam (Jakarta: Gema Insani Press, 2001$), 100$.
} 


\begin{tabular}{|c|c|c|c|}
\hline 3 & $\begin{array}{l}\text { Modal Kerja } \\
\text { a. UMKM } \\
\text { b. } \text { Bukan UMKM }\end{array}$ & $\begin{array}{ll}\text { a. } & 30.735 \\
\text { b. } & 47.606\end{array}$ & $\begin{array}{ll}\text { a. } & 14 \% \\
\text { b. } & 21,8 \%\end{array}$ \\
\hline 4 & TOTAL & 218.697 & 100 \\
\hline
\end{tabular}

Sumber : Otoritas Jasa Keuangan. Statistik Perbankan Syariah 2019 (Data diolah)

Data di atas menujukkan porsi pembiayaan yang disalurkan bank syariah pada periode Oktober 2019. Porsi pembiayaan terbesar disalurkan untuk kegiatan konsumtif sebesar 41 persen. Adapun pembiayaan dengan jenis pembiayaan produktif bentuk investasi diberikan pada bukan UMKM sebesar 14,8 persen. Begitupun pada pembiayaan produktif modal kerja terbesar disalurkan pada bukan UMKM sebesar 21,8 persen. Hal ini menunjukkan bahwa penyaluran pembiayaan di bank syariah tidak menjadikan UMKM sebagai prioritas dalam pembiayaan.

Dari uraian di atas perlu upaya dalam mengembangkan ekonomi Islam, dalam bentuk menetukan fokus untuk arah segmen yang dapat menjadi sumber pengembangannya. Segmen yang dianggap relevan bagi perkembangan ekonomi Islam, yaitu segmen UMKM. Semua lembaga-lembaga keuangan Islam dapat dirahkan untuk dapat memberikan dukungan bagi UMKM dan menjadi identitas ekonomi Islam itu sendiri.

Dini Arwati menyebutkan bahwa perbankan syariah lebih tepat memilih mitra kerjanya kepada UMKM yang jumlahnya banyak. Sesungguhnya pemahaman mengenai ekonomi syariah, penerapan akuntansi syariah, penyaluran pembiayaan syariah dan penghimpunan dana syariah lebih cepat dan sesuai sasaran. Untuk menetapkan besarnya bagi hasil dalam pembiayaan syariah ini tentunya diperlukan perangkat yang standar. Informasi ini biasanya disebut dengan laporan keuangan. Dalam hubungan perbankan syariah maupun non syariah dengan UKM, maka dari pihak UKM harus bisa menyediakan laporan keuangan yang dapat diandalkan. $^{7}$

Miftahul Khaerani dan Marlina Ekawati dalam papernya yang berjudul "Zakat Produktif dan Perannya terhadap Perkembangan UMKM Studi Pada LAZ el-Zawa UIN Maulana Malik Ibrahim Malang" menyebutkan bahwa penyaluran produktif kreatif dilakukan dalam program qard al-hasan UMKM dan mudārabah UMKM. Jumlah zakat produktif berpengaruh terhadap perkembangan usaha mikro mustahiq. Semakin tinggi jumlah zakat produktif yang diterima mustahiq, maka usaha mikro mustahiq semakin berkembang. Lama usaha dan jenis kelamin didapatkan berpengaruh juga terhadap perkembangan usaha mustahiq. Diharapkan LAZ el-Zawa bisa meningkatkan dana zakat untuk tujuan produktif kreatif bagi mustahiq UMKM, sehingga lebih banyak lagi UMKM yang bisa dibantu, sehingga diharapkan dapat mengurangi kemiskinan. ${ }^{8}$

Raihanah Daulay menyebutkan bahwa banyak faktor yang menyebabkan kondisi usaha mikro sulit untuk dapat berkembang. Di antaranya kurangnya modal dan kemampuan sumber

\footnotetext{
${ }^{7}$ Dini Arwati, "Peran Strategis Ekonomi Berbasis Syariah dalam Pemberdayaan Ekonomi Sektor Usaha Mikro, Kecil, dan Menengah (UMKM) Ditinjau dari Penerapan Akuntasi Syariah dan Akuntansi UMKM", Journal Bisnis, Manajemen dan Ekonomi, Volume 9, Nomor 9 (Juni 2009), 228.

${ }^{8}$ Miftahul Khairani dan Marlina Ekawaty, "Zakat Produktif dan Perannya terhadap Perkembangan UMKM Studi Pada LAZ el-Zawa UIN Maulana Malik Ibrahim Malang", Seminar Nasional \& Call for Papers "Peluang dan Tantangan Pengembangan UMKM dan Ekonomi Kreatif dalam Era Global dan Digital, Bali 5 Mei 2017, Undiknas, 15.
} 
daya manusia untuk mengembangkan usaha agar dapat bersaing. Banyaknya persaingan dari usaha yang memiliki modal lebih besar menjadi faktor utama yang menjadi penyebab persaingan yang tidak seimbang bagi usaha mikro. Pemerintah perlu untuk melakukan proteksi bagi usaha mikro agar tetap dapat bertahan melalui peraturan daerah. Umat Islam dapat mengambil peran dengan memberikan pengetahuan yang menambah wawasan melalui penyuluhan kepada masyarakat sebagai bentuk dari muamalah. Pemerintah perlu memperhatikan sistem ekonomi yang lebih sesuai dengan sistem sosial masyarakat Indonesia serta mengevaluasi konsep pembangunan ekonomi dan distribusi yang selama ini masih mengalami ketidakadilan. ${ }^{9}$

Usaha mikro merupakan usaha yang dikelola oleh individu atau keluarga atau beberapa orang yang belum memiliki izin usaha secara lengkap. ${ }^{10}$ Dalam Undang-Undang Nomor 20 tahun 2008 tentang UMKM bahwa unit usaha mikro adalah usaha produktif yang dimiliki orang per orang dan atau badan usaha perorangan yang memenuhi kriteria usaha mikro sebagaimana yang diatur dalam udang-undang. Sedangkan menurut Musa Hubeis, usaha kecil yang benar-benar kecil dan mikro dapat dikelompokkan atas pengertian 1) usaha kecil mandiri, yaitu tanpa menggunakan tenaga kerja lain; 2) usaha kecil yang menggunakan tenaga kerja anggota keluarga sendiri; dan 3) usaha kecil yang memiliki tenaga kerja upahan yang tetap. Usaha kecil dengan kategori yang dimaksud adalah yang sering dipandang sebagai usaha yang banyak menghadapi kesulitan, terutama yang terkait dengan lemahnya kemampuan manajerial, teknologi, dan permodalan yang terbatas, SDM, pemasaran, dan mutu produk. Faktor eksternal dalam usaha kecil merupakan hambatan yang sulit diatasi, yaitu struktur pasar yang kurang sehat dan berkembangnya perusahaan-perusahaan asing yang menghasilkan produk sejenis untuk segmen pasar yang sama. ${ }^{11}$

Syariat atau hukum Islam sifatnya wajib dipatuhi, sehingga menentukan corak perekonomian Islam. Misalnya dalam bidang keuangan, pelarangan riba dan maysir akan menjadikan sektor ekonomi produktif (sektor riil) sebagai satu-satunya tempat untuk memperoleh profit. Mendorong pemilik dana untuk ke sektor ekonomi produktif memproduksi barang dan jasa berdasarkan aktivitas yang berbasis jual beli dan investasi (bagi hasil). Dari sinilah pemilik dana memperoleh keuntungan yang halal dan aktivitas perekonomian berjalan lancar. ${ }^{12}$

Salah satu upaya untuk mengembangkan akses permodalan bagi UMKM adalah melalui pembiayaan syariah. Paling tidak, ada empat jalur pembiayaan syariah bagi UMKM di tanah air. Jalur pembiayaan syariah untuk UMKM terdiri dari jalur perbankan syariah (BUS, UUS, dan BPRS) dengan target UMKM. Kemudian BMT (koperasi syariah) dan program pemerintah untuk UMKM dan BAZNAS dan LAZ untuk usaha mikro. Rata-rata pertumbuhan pembiayaan UMKM pada BUS dan UUS selama lima tahun terakhir mencapai 33 persen sedangkan BPRS mencapai angka rata-rata 32 persen. BMT dan koperasi syariah sejatinya adalah institusi yang memang dikhususkan pada pengembangan UMKM by nature. Jalur

\footnotetext{
${ }^{9}$ Raihanah Daulay, "Pengembangan Usaha Mikro untuk Perbedayaan Ekonomi Ummt Islam di Kota Medan", Jurnal MIQOT, Volume XL, Nomor 1 (Januari-Juni 2016), 64.

${ }^{10}$ Nizarul Alim, Pembiayaan Syari'ah untuk Usaha Mikro dan Kecil: Studi Kasus dan Solusi, cet. I (Surabaya: PT. Bina Ilmu, 2009), 14.

${ }^{11}$ Musa Hubeis, Prospek Usaha Kecil dalam Wadah Inkubator Bisnis, cet. I (Bogor: Galia Indonesia, 2009$), 18$.

${ }^{12}$ Bank Indonesia, Masa Depan Keuangan Syariah Indonesia (Bogor: TAZKIA Publishing, 2019), 13.
} 
Badan Amil Zakat Nasional (BAZNAS) dan lembaga Amil Zakat (LAZ) adalah jalur yang dikhususkan bagi para mustahiq, yang keseluruhannya berada pada kategori usaha mikro. Pola yang dikembangkan adalah dengan program pemberdayaan produktif. ${ }^{13}$

Penyaluran pembiayaan diawali dengan penetapan tujuan strategis. Hal tersebut mencakup penetapan segmen pasar, sektor industri, target pertumbuhan, dan penetapan tingkat risiko yang akan diambil. Tujuan strategis ini akan memberikan dampat pada tata cara, organisasi, dan instruktur penyaluran pembiayaan. Alokasi sumber daya dan kegiatan pemasaran yang akan dijalankan oleh bank. Fungsi strategis penyaluran pembiayaan dilakukan oleh direksi dengan persetujuan komisaris. Kebijakan strategis dalam bidang pembiayaan dibentuk unit kerja yang bertugas merancang produk, menyusun ketentuan dan prosedur yang menjadi pedoman bagi unit kerja lain dalam menjalankan tugas. ${ }^{14}$

\section{Metode Penelitian}

Jenis penelitian yang digunakan dalam tulisan ini adalah penelitian pustaka (library reserach) yang bersumber dari beberapa literatur dan data yang telah disajikan dari beberapa instansi yang berkaitan dengan ekonomi Islam dan Usaha Mikro Kecil dan Menengah UMKM. Bebrapa sumber dijadikan rujukan dalam penelitian ini seperti buku, majalah, dan sumber lainnya yang dianggap relevan. Sifat penelitian dalam paper ini adalah penelitian kualitatif yang menguraikan tentang perkembangan UMKM dan kontribusi perbankan syariah dan tentang ekonomi Islam.

Adapun yang menjadi sumber data dalam penelitian ini adalah data sekunder yang bersumber dari beberapa lembaga yang telah disajikan, kemudian digunakan dan diolah oleh peneliti. Kemudian memberikan penjabaran dari data yang telah disajika tersebut. Untuk teknik pengumpulan data yang digunakan adalah melalui beberapa data yang telah disajikan yang terkait dengan ekonomi Islam dan UMKM kemudian data tersebut diolah dan kemudian dijabarkan.

Adapun teknik analisis data yang digunakan adalah deskriptif kualitatif, yaitu menjabarkan dari data yang telah dikumpulkan yang terkait dengan ekonomi Islam dan UMKM. Kemudian memberikan gambaran dari hasil yang diperoleh, kemudian menjabarakan dari hasil yang telah diperoleh.

\section{Perkembangan UMKM di Indonesia Tahun 2017-2018}

Pada periode tahun 2017 sampai tahun 2018, menunjukkan bahwa semua jenis UMKM mengalami pertumbuhan mencapai lebih dari 3 persen. Pertumbuhan terbesar pada jenis UMKM usaha menengah, yaitu tumbuh 3,54 persen, lalu usaha kecil sebesar 3,54. Sedangkan jumlah UMKM terbesar pada jenis usaha mikro dengan porsi 98,685 persen dengan jumlah usaha 63.350.222. Secara rata-rata, jumlah usaha UMKM pada tahun 2018 mencapai 21.398.018,67 unit usaha. Penjelasan ini menunjukkan adanya perkembangan Usaha Mikro, Kecil dan Menengah (UMKM).

\footnotetext{
13 Irfan Syauqi Beik dan Laily Dwi Arsyianti, Ekonomi Pembangunan Syariah, edisi revisi (Jakarta: Raja Grafindo Persada, 2016), 133-134.

${ }^{14}$ Ikatan Bankir Indonesia, Mengelola Bisnis Pembiayaan Bank Syariah Jakarta: PT. Gramedia Pustaka Utama, 2018), 12.
} 
Tabel 1.2. Perkembangan UMKM di Indonesia Tahun 2017-2018

\begin{tabular}{|c|l|c|c|c|l|}
\hline No & \multicolumn{1}{|c|}{$\begin{array}{c}\text { Usaha Mikro, Kecil dan } \\
\text { Menegah }\end{array}$} & Jumlah 2017 & Jumlah 2018 & Perkembangan & Porsi \\
\hline 1 & Usaha Mikro (UMi) & 62.106 .900 & 63.350 .222 & 2,00 & 98,685 \\
\hline 2 & Usaha Kecil (UK) & 757.090 & 783.132 & 3,44 & 1,219 \\
\hline 3 & Usaha Menengah (UM) & 58.627 & 60.702 & 3,54 & 0,096 \\
\hline 4 & TOTAL & 62.922 .617 & 64.194 .056 & 2,02 & 100 \\
\hline 5 & RATA-RATA & $20.974 .205,67$ & $21.398 .018,67$ & - & - \\
\hline
\end{tabular}

Sumber Data : Kementerian Koperasi dan Kecil dan Menengah yang diolah dari data Badan Pusat Statistik (BPS) (Data diolah)

\section{Pertumbuhan Pembiayaan Bank Syariah}

Tabel 1.3. Pertumbuhan Pembiayaan Bank Syariah

\begin{tabular}{|c|c|c|c|c|c|}
\hline No & Jenis Bank Syariah & $\begin{array}{c}\text { Jenis } \\
\text { Pembiayaan } \\
\text { Bank Syariah } \\
\end{array}$ & $\begin{array}{l}\text { Desember } \\
2018\end{array}$ & Oktober 2019 & $\begin{array}{c}\text { Pertumbuhan } \\
\%\end{array}$ \\
\hline \multirow{3}{*}{1} & \multirow{3}{*}{ Bank Umum Syariah } & Konsumtif & 81.100 .000 & $89.638,000$ & 10,53 \\
\hline & & $\begin{array}{l}\text { Produktif } \\
\text { Investasi }\end{array}$ & 48.773 .000 & $50.718,000$ & 4 \\
\hline & & $\begin{array}{l}\text { Produktif } \\
\text { Modal Kerja }\end{array}$ & 72.425 .000 & $78.341,000$ & 8,2 \\
\hline \multirow{3}{*}{2} & \multirow{3}{*}{ Unit Usaha Syariah } & Konsumtif & 58.308 .000 & $64.111,000$ & 9,95 \\
\hline & & $\begin{array}{l}\text { Produktif } \\
\text { Investasi }\end{array}$ & 26.957 .000 & $32.552,000$ & 20,75 \\
\hline & & $\begin{array}{l}\text { Produktif } \\
\text { Modal Kerja }\end{array}$ & 32.630 .000 & $29.924,000$ & $-8,29$ \\
\hline \multirow{3}{*}{3} & \multirow{3}{*}{$\begin{array}{c}\text { Bank Pembiayaan } \\
\text { Rakyat Syariah }\end{array}$} & Konsumtif & 4.338 .594 & $4.780,773$ & 10,19 \\
\hline & & $\begin{array}{l}\text { Produktif } \\
\text { Investasi }\end{array}$ & 1.317 .166 & $1.553,855$ & 17,96 \\
\hline & & $\begin{array}{l}\text { Produktif } \\
\text { Modal Kerja }\end{array}$ & 3.428 .706 & $3.887,552$ & 13,38 \\
\hline
\end{tabular}

Sumber: Otoritas Jasa Keuangan (OJK). Statistik Perbankan Syariah Oktober 2019 (Data diolah)

Dari data di atas menunjukkan adanya perkembangan produk pembiayaan pada tiga jenis bank syariah pada periode Oktober Tahun 2019, terdiri dari Bank Umum Syariah (BUS), Unit Usaha Syariah (UUS) dan Bank Pembiayaan Rakyat Syariah (BPRS). Pada BUS pertumbuhan terbesar pada pembiayaan konsumtif yang tumbuh sebesar 10,53 persen. Sedangkan pertumbuhan terkecil pada produk pembiayaan investasi hanya sebesar 4 persen. Adapun pada UUS pertumbuhan pembiayaan terbesar pada pembiayaan sebesar 20,75 persen. Sedangkan pembiayaan modal kerja mengalami penurunan sebesar 8,29 persen. Kemudian pada BPRS pertumbuhan pembiayaan 17,96 persen. Sedangkan pertumbuhan terkecil pada pembiayaan 10,19 persen. 
Jika berdasakan data di atas banwa bank syariah yang merupakan lembaga ekonomi Islam masih didominasi pada penyaluran pembiayaan konsumtif padahal secara prinsip ekonomi Islam hadir untuk lebih menggerakkan sektor riil, khususnya pada sektor produktif. Data sebelumnya, UMKM mengalami pertumbuhan dan sering menjadi kendala dari UMKM dari sisi modal. Seandainya bank syariah dapat didorong untuk mendukung sektor riil produktif dengan mengutamakan produktif untuk UMKM.

\section{Penguatan Ekonomi Islam melalui Penguatan Sektor Riil UMKM}

Selain bank syariah, ada beberapa lembaga-lembaga ekonomi Islam yang juga mengalami pertumbuhan, dan memiliki peran dalam mengembangkan sktor riil UMKM. Lembaga-lembaga itu berupa Lembaga Keuangan Mikro Syariah (LKMS), IKNB Syariah, dan Lembaga Sosial.

Tabel 1.4. Perkembangan Lembaga Keuangan Mikro Syariah Desember 2018

\begin{tabular}{|c|l|c|c|c|}
\hline No & \multicolumn{1}{|c|}{ Komponen } & Tahun 2017 & Tahun 2018 & Pertumbuhan \\
\hline 1 & Aset & 99,96 & 247,34 & $147,4 \%$ \\
\hline 2 & Dana Syirkah Temporer & 55,17 & 111,16 & $101,5 \%$ \\
\hline 3 & Modal & 5,30 & 8,04 & $51,6 \%$ \\
\hline 4 & Sisa Hasil Usaha & 18,96 & 95,28 & $403,5 \%$ \\
\hline 5 & Cadangan & 1,51 & 1,31 & $-13,2 \%$ \\
\hline
\end{tabular}

Sumber: Otoritas Jasa Keuangan (OJK), Statistik Bulanan IKNB Syariah Desember 2018

Dari data di atas yang dikeluarkan oleh OJK untuk periode Desember 2017 sampai dengan 2018 menunjukkan adanya pertumbuhan yang sangat baik dari lembaga keuangan. Pertumbuhan terbesar pada komponen sisa hasil usaha, yaitu sebesar 403,5 persen. Pertumbuhan terkecil pada komponen modal tumbuh sebesar 51,6 persen, adapun yang mengalami penurunan adalah komponen cadangan yang mengalami penurunan sebesar -13,2 persen. Dalam performa seperti ini, lembaga keuangan mikro syariah harus tetap menjaga keuangan yang dimilikinya khususnya dalam kompetisi mendapatkan pangsa pasar. Kondisi ekonomi yang belum stabil mengharuskan lembaga keuangan syariah untuk bisa meningkatkan cadangan pendapatannya.

Tabel 1.5. Perkembangan IKNB Syariah Desember 2018

\begin{tabular}{|c|l|c|c|c|}
\hline No & \multicolumn{1}{|c|}{ Komponen } & Tahun 2017 & Tahun 2018 & Pertumbuhan \\
\hline 1 & Jumlah Lembaga IKNB & 54 & 89 & $64,81 \%$ \\
\hline 2 & Aset & 99.133 & 96.905 & $-5,22 \%$ \\
\hline 3 & Ekuitas & 42.721 & 43.541 & $1,92 \%$ \\
\hline 4 & Aset Produktif & 66.755 & 65.174 & $-2,37 \%$ \\
\hline 5 & Liabilitas & 51.065 & 51.654 & $1,15 \%$ \\
\hline
\end{tabular}

Sumber: Otoritas Jasa Keuangan (Statistik IKNB Syariah Desember 2018) (Data Olah)

Data di atas menunjukkan adanya pertumbuhan dari industri keuangan non bank syariah (IKNB Syariah) yang juga merupakan lembaga ekonomi Islam di Indonesia. IKNB Syariah terdiri dari beberapa lembaga, yaitu lembaga asuransi syariah, lembaga pembiayaan syariah, lembaga dana pensiun syariah, lembaga jasa khusus syariah, dan lembaga keuangan mikro syariah. Dari data di atas menunjukkan pertumbuhan IKNB Syariah pada periode Desember 
2017 sampai dengan desember 2018. Beberapa komponen mengalami pertumbuhan positif namun ada komponen yang mengalami penurunan. Komponen yang mengalami pertumbuhan terbesar adalah jumlah lembaga IKNB Syariah yang tumbuh sebesar 64,81 persen atau bertembah 35 lembaga di tahun 2018. Kemudiat pertumbuhan ekuitas, yaitu tumbuh sebesar 1,92 persen. Adapun komponen aset IKNB Syariah mengalami penurunan sebesar 5,22 persen.

IKNB Syariah menjadi pelengkap dari perbankan syariah yang memberi akses layanan kepada masyarakat. Keberdaan IKNB Syariah belum begitu besar dikenal di tengah masyarakat. Hal ini sangat berpengaruh terhadap perkembangan IKNB Syariah. Dibutuhkan upaya dorongan dari semua pihak untuk menumbuhkan IKNB Syariah agar dapat lebih berkontribusi bagi perekonomian dan masyarakat. Variasi produk dari IKNB Syariah menjadikannya memberi penawaran kepada masyarakat yang menghendaki jasa layanan keuangan syariah selain perbankan syariah. Produk-produk dari IKNB syariah bisa menjadi pilihan dalam kegiatan berekonomi masyarakat. Hanya saja membutuhkan upaya memperkenalkannya di tengah masyarakat agar dapat terus tumbuh dan ikut mendorong perkembangan ekonomi.

Tabel 1.6. Pertumbuhan Penghimpunan Dana Sosial Pada Lembaga Amil Zakat (LAZ)

\begin{tabular}{|c|l|c|c|c|}
\hline No & \multicolumn{1}{|c|}{ Lembaga Zakat } & $\begin{array}{c}\text { Penghimpunan Dana } \\
\text { Sosial Tahun 2016 }\end{array}$ & $\begin{array}{c}\text { Penghimpunan Dana } \\
\text { Sosial Tahun 2017 }\end{array}$ & $\begin{array}{c}\text { Pertumbuhan } \\
\%\end{array}$ \\
\hline 1 & BAZNAS & 111.690 .914 .428 & 92.568 .574 .079 & $-17,12$ \\
\hline 2 & BAZNAS Provinsi & 192.609 .000 .494 & 644.859 .329 .420 & 234,80 \\
\hline 3 & BAZNAS Kabupaten/ Kota & 3.311 .745 .042 .024 & 876.626 .483 .800 & $-73,53$ \\
\hline 4 & LAZ Lainnya & 1.401 .248 .170 .005 & 2.039 .218 .862 .993 & 45,53 \\
\hline 5 & Total & 5.017 .293 .126 .950 & 3.653 .273 .250 .292 & $-21,19$ \\
\hline
\end{tabular}

Sumber: Dokumen Statistik BAZNAS 2016 dan 2017 (Data Diolah)

Dari data di atas menunjukkan adanya pertumbuhan dana sosial yang berhasil dihimpun oleh lembaga zakat dalam hal ini adalah Badan Amil Zakat (BAZNAS) baik pusat maupun daerah dan lembaga amil zakat lainnya yang ada dan resmi. Zakat dan dana sosial atau dana kebajikan lainnya merupan bagian dari instrumen yang dimiliki oleh ekonomi Islam untuk mendistribusikan kekayaan (harta) bagi semua manusia agar harta tidak menumpuk dan hanya dinikmati oleh segelintir orang. Data di atas menunjukkan adanya pertumbuhan penghimpunan dana sosial melalui Lembaga Amil Zakat pada tahun 2016 dan tahun 2017. Pertumbuhan terbesar pada penghimpinan dana yang dilakukan oleh BAZNAS Provinsi yang tumbuh sangat besar mencapai 234,80 persen, pertumbuhan selanjutnya juga terlihat pada LAZ lainnya yang tumbuh sebesar 45,53 persen. Adapun penghimpunan dana pada BAZNAS pusat mengalami penurunan sebesar 17,12. Begitupun secara total penghimpunan dana sosial yang mengalami penurunan sebesar 21,19 persen.

Tabel 1.7. Pertumbuhan Jumlah Penghimpunan Dana Berdasarkan Jenis Dana

\begin{tabular}{|c|l|c|c|c|}
\hline No & Jenis Dana & $\begin{array}{c}\text { Penghimpunan } \\
\text { Dana Sosial } \\
\text { Tahun 2015 }\end{array}$ & $\begin{array}{c}\text { Penghimpunan } \\
\text { Dana Sosial } \\
\text { Tahun 2016 }\end{array}$ & Pertumbuhan \% \\
\hline 1 & Zakat & 3.738 .216 .792 .496 & 2.312 .195 .596 .498 & $-38,15$ \\
\hline
\end{tabular}




\begin{tabular}{|c|l|l|l|c|}
\hline 2 & Infak/Sedekah & 1.001 .498 .305 .006 & 1.176 .558 .166 .696 & 17,48 \\
\hline 3 & $\begin{array}{l}\text { Dana Sosial Keagamaan } \\
\text { Lainnya }\end{array}$ & 277.336 .514 .452 & 163.986 .086 .154 & $-40,87$ \\
\hline 4 & Dana Sosial Lainnya & $241,514,997$ & 533.400 .945 & 120,86 \\
\hline 5 & Jumlah & 5.017 .293 .126 .950 & 3.653 .273 .250 .292 & $-21,19$ \\
\hline
\end{tabular}

Sumber : Dokumen Statistik BAZNAS 2016 (Data diolah)

Data di atas menunjukkan pertumbuhan penghimpunan dana sosial berdasarkan jenis dana yang berhasil dihimpun oleh Lembaga Amil Zakat (LAZ). Pertumbuhan penghimpunan dana sosial pada periode tahun 2015 dan tahun 2016 pada jenis zakat mengalami penurunan sebesar 38,15 persen, sedangkan pada jenis infak dan sedekah mengalami pertumubah 17,48 pesen. Adapun dana-dana sosial lain yang berhasil dihimpun tumbuh mencapai 120,86 persen.

Hadirnya Lembaga Amil Zakat untuk menghimpun dana sosial sangat baik, dan sosial dapat teroganisir secara baik, begitupun dengan penyalurannya. Data penghimpunan dana sosial dapat diketahui, penyalurannya juga diharapkan dapat tepat sasaran sesuai dengan jenis dana sosialnya. Lembaga Amil Zakat menjadi wadah bagi perorangan atau lembaga yang hendak mengeluarkan dana sosialnya baik itu zakat maupun infak dan sedekah. Peran dan keberadaan zakat perlu didorong dan didukung dari semua pihak mengingat saat ini pola hidup islami semakin marak di tengah masyarakat. Banyak masyarakat yang hendak berbagi dengan sesama yang sedang membutuhkan. Khususnya ketika terjadi bencana kesadaran masyarakat untuk berbagi dan peduli semakin nampak terlihat.

Ekonomi Islam memiliki lembaga-lembaga yang dapat dijadikan upaya untuk mendorong perekonomi suatu negara. Lembaga-lembaga yang dimiliki cukup lengkap dan banyak sehingga sangat mudah untuk berkontribusi dalam pengembangan tingkat ekonomi. Ekonomi Islam yang banyak dilirik oleh negara-negara di dunia bahkan perkembangan di negara lain lebih besar sehingga menjadikan tantangan bagi Indonesia untuk menetukan arah perkembangan ekonomi yang dimilikinya. Perlu ditentukan segmen dan fokus yang ingin dimanfaatkan sebagai jalan dan rujukan untuk perkembangan ekonomi Islam. Selain sebagai fokus dan juga sebagai identitas pada segmen yang ekonomi Islam dapat dikembangkan sehingga bisa berkompetisi secara global.

Segmen pengembangan UMKM menjadi tepat, melihat kondisi UMKM yang terus berkembang, untuk bisa mendapatkan akses dari lembaga-lembaga keuangan Islam. UMKM banyak di Indonesia dan menyebar dengan luas, dan dapat diakses masyarakat secara menyeluruh, serta kekuatan dan keberadaanya banyak menyerap tenaga kerja. Ekonomi Islam dapat dikembangkan dengan penguatan pada sektor riil UMKM. Mengingat bahwa ekonomi Islam memiliki sistem bagi hasil yang menjadi pembedanya dengan sistem ekonomi konvensional. Sistem bagi hasil hanya dimiliki oleh ekonomi Islam, dengan memberikan keadilan bagi pelaku ekonomi. Hal ini akan memudahkan sistem bagi hasil untuk digunakan dalam mengembangkan UMKM.

\section{Kesimpulan}

Pertumbuhan Usaha Mikro, Kecil, dan Menengah (UMKM) mengalami pertumbuhan pada tahun 2018. Jenis UMKM yang mengalami pertumbuhan terbesar adalah usaha menengah dengan pertumbuhan 3,54 persen, dan selanjutnya usaha kecil tumbuh sebesar 3,44 
persen. Adapun jenis usaha terbanyak yaitu usaha mikro dengan porsi 98,7 persen. Sedangkan alokasi penyaluran pembiayaan bank syariah masih didominasi oleh pembiayaan untuk konsumtif bukan produktif. Hal ini menjadikan bank syariah perlu didorong untuk banyak memberikan pembiayaan produktif, khususnya untuk pembiayaan bagi UMKM.

Ekonomi Islam hadir untuk mengembangkan dan mengedepankan sektor riil, sehingga ekonomi Islam dapat berkontribusi bagi negara. Untuk bersaing secara global Indonesia perlu menentukan fokus dan memilih segmen yang tepat untuk dikembangkan oleh ekonomi Islam. Cakupan ekonomi Islam yang begitu luas, mengakibatkan ekonomi Islam secara global lebih berkembang diberbagai negara. Penentuan segmen dan fokus menjadi penting dalam menentukan arah perkembangan ekonomi Islam. Salah satu segmen yang tepat dan dapat menjadi kekuatan ke depan dengan melihat karateristik bangsa Indonesia, yaitu ekonomi Islam dengan meningkatkan UMKM. Selain bank syariah ekonomi Islam memiliki lembagalembaga yang dapat berkontribusi bagi perkembangan UMKM, seperti BMT/Koperasi Syariah, Industri Keuangan non Bank (IKNB), dan lembaga sosial (BAZ dan LAZ). Selain itu sistem bagi hasil yang merupakan ciri pembeda ekonomi Islam sangat relevan jika diterapakan untuk memberikan permodalan bagi UMKM.

\section{Daftar Rujukan}

al-Mishri, Abdul Sami'. Pilar-Pilar Ekonomi Islam. Yogyakarta: Pustaka Pelajar, 2006.

al-Nabhani, Taqiyyuddin. Membangun Sistem Ekonomi Alternatif, Perpektif Islam. Surabaya: Risalah Gusti, 2009.

Alim, Nizarul. Pembiayaan Syari'ah untuk Usaha Mikro dan Kecil: Studi Kasus dan Solusi. Surabaya: PT. Bina Ilmu, 2009.

Arwati, Dini. "Peran Strategis Ekonomi Berbasis Syariah Dalam Pemberdayaan Ekonomi Sektor Usaha Mikro, Kecil, dan Menengah (UMKM), Ditinjau Dari Penerapan Akuntasi Syariah dan Akuntansi UMKM", Journal Bisnis, Manajemen dan Ekonomi, Volume 9, Nomor 9 (Juni 2010).

Badan Amil Zakat Nasional. Statistical Document of BAZNAS 2016 and 2017.

Bank Indonesia. Masa Depan Keuangan Syariah Indonesia. Bogor: TAZKIA Publishing, 2019.

Chapra, M. Umar. Masa Depan Ilmu Ekonomi Sebuah Tinjauan Islam. Jakarta: Gema Insani Press, 2001.

Condro, Dwi Triono. Ekonomi Pasar Syariah Ekonomi Islam Madzhab Hamfara, Jilid 2. Yogyakarta: Irtikaz, 2017.

Daulay, Raihanah. "Pengembangan Usaha Mikro untuk Perbedayaan Ekonomi Umat Islam di Kota Medan”, Journal MIQOT, Volume XL, Nomor 1 (Januari-Juni 2016).

Hubeis, Musa. Prospek Usaha Kecil Dalam Wadah Inkubator Bisnis, cet. I. Bogor: Galia Indonesia, 2009.

Ikatan Bankir Indonesia. Mengelola Bisnis Pembiayaan Bank Syariah. Jakarta: PT. Gramedia Pustaka Utama, 2018.

Karim, Adiwarman A. Ekonomi Mikro Islam, edisi 3. Jakarta: PT Raja Grafindo Persada, 2006.

Khairani, Miftahul dan Marlina Ekawaty. "Zakat Produktif dan Perannya terhadap 
Perkembangan UMKM Studi pada LAZ el-Zawa UIN Maulana Malik Ibrahim Malang", Seminar Nasional Peluang dan Tantangan Pengembangan UMKM dan Ekonomi Kreatif dalam Era Global dan Digital, Bali 5 Mei 2017, Undiknas.

Otoritas Jasa Keuangan (OJK). Statistik Bulanan IKNB Syariah Desember 2018.

Otoritas Jasa Keuangan (OJK). Statistik Perbankan Syariah Oktober 2019.

P3EI UII. Ekonomi Islam. Jakarta: PT. Raja Grafindo Persada, 2008.

Syauqi, Irfan Beik dan Laily Dwi Arsyianti. Ekonomi Pembangunan Syariah, edisi revisi. Jakarta: Raja Grafindo Persada, 2016. 